\title{
Induce Physical and Chemical Mutagenesis for Improvement of Yield Attributing Traits and their Correlation Analysis in Chickpea
}

\author{
Aamir Raina ${ }^{1, a}$, Rafiul Amin Laskar ${ }^{1, b}$, Shahnawaz Khursheed ${ }^{1, c, *}$, \\ Samreen Khan ${ }^{1, \mathrm{~d}}$, Kouser Parveen ${ }^{2, \mathrm{e}}$, Ruhul Amin ${ }^{1, \mathrm{f}}$ and Samiullah Khan ${ }^{1, \mathrm{~g}}$ \\ ${ }^{1}$ Mutation Breeding Lab. Department of Botany, Aligarh Muslim University, Aligarh, 202002. \\ ${ }^{2}$ Amar Singh College, Gogji Bagh, Srinagar, J\&K, India

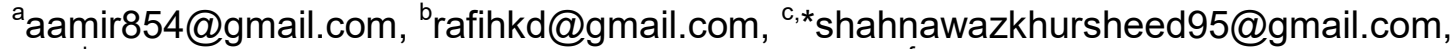 \\ dmskamu@gmail.com, ${ }^{\mathrm{d}}$ kouserwani@gmail.com, ${ }^{\mathrm{f}}$ ruhulamin4849@gmail.com, \\ gkhan_drsami@yahoo.co.in
}

Keywords: Gamma rays, Sodium azide (SA), Hydrazine hydrate (HZ), Cicer arietinum L.

\begin{abstract}
In the current scenario of sky high population and widespread food insecurity, there is an urgent need for productivity improvement of major crops like pulses, one of the most climate friendly and accessible foods for the large poor population of the world. Chickpea is an important pulse crop, having high percentage of nutritional content and is widely used as food across the world. Induced mutagenesis has proved over time as a coherent tool for modern plant breeders to improve the productivity for combating the food insecurity and malnutrition across the globe. Dry and healthy seeds of Cicer arietinum L. var. C-235 were treated with individual and combination doses of gamma rays, sodium azide and hydrazine hydrate to raise the $M_{1}$ generation. $M_{2}$ seeds harvested from $\mathrm{M}_{1}$ plants were sown in the nest season. Bio-physiological study in $\mathrm{M}_{1}$ generation showed growth inhibition in the order viz. combination treatment $>$ hydrazine hydrate $>$ gamma rays $>$ sodium azide. In $\mathrm{M}_{2}$ generation, comparative observations were recorded for morphological variation and quantitative traits to assess the genetic response of the chickpea variety $\mathrm{C}-235$ toward the different concentrations of mutagens. Observations on isolated mutants in $\mathrm{M}_{2}$ generation revealed that $0.3 \% \mathrm{HZ}+0.02 \% \mathrm{SA}$ was most mutagenic while $200 \mathrm{~Gy}, 0.03 \% \mathrm{SA}$ and $0.2 \% \mathrm{HZ}$ were highest in their individual treatment groups. In context to the frequency of morphological mutants studied in $\mathrm{M}_{2}$ generation, dwarf mutants were found to be highest followed by tall and branching pattern mutants. Highly significant correlation coefficient between yield and other traits showed that the selection for high yielding mutants can be done on the basis of these traits undoubtedly.
\end{abstract}

\section{Introduction}

Mutation breeding is one of the most important and reliable technique in improving the genotype of crop plants [1]. The genetic makeup of economic crops has been improved by mutation breeding along with significant increase in crop production $[2,3]$. The improvement of economic traits and quality characters for improvement of crop within the short period of time can be achieved by the help of induced mutagenesis $[5,6]$. Induced morphological mutants are useful for the development of improved varieties when they are used in cross breeding programmes $[4,7,8]$. Chickpea (Cicer arietinum L.) is an important nutritional pulse crop. Its seeds are rich in proteins, carbohydrates, fats and other essential nutritive components. The seeds are rich and cheap source of dietary nutrients and are useful for malnourished people [11]. The origin of Chickpea is believed to be in south eastern Turkey and adjoining areas of Iraq, Iran and former Soviet Union [12]. Chickpea ranks second food legume and third largest grown pulses of the world [24]. In India, chickpea is cultivated under 8.21 million hectares of area with an annual production of 7.35 million tones, average yield is $895 \mathrm{~kg} / \mathrm{ha}$ and average growth rate production was 4.58 percent [25]. Considering the rapidly increasing population and declining per capita pulses consumption in India, while also considering comparatively large area under its cultivation then other pulses, the chickpea production statistics over the last decade is not sufficient to meet the growing demand. Therefore, 
attempts are needed to crack the stagnation of chickpea productivity by develop high yielding and better adapted varieties. Plant breeding requires genetic variation of useful traits for crop improvement and chickpea, being a self-pollinated crop, lacks the sufficient natural variability. So, in order to break the genetic bottleneck of the chickpea genotypes developed in due course by different agronomical practices, the possibility offered by induce mutagenesis is tremendous and of extreme importance. The main purpose of this work was to evaluate the mutagenicity of gamma rays, HZ and SA doses employed and the magnitude of variability induced in various morphological and quantitative traits of the chickpea genotype C-235 for the practicable selection based on yield attributing traits.

\section{Materials and Methods}

Fresh and healthy seeds of Cicer arietinum L. var. C-235 obtained from Government Seed Store, Aligarh, India were used for this experiment. 13 sets of seeds each containing 42 seeds were used in this experiment. Out of these 13 sets, one set was kept as control whereas, the rest were equally used for treatments of gamma rays, HZ and SA. The doses of mutagens selected in this experiment were finalised from the in vitro germination test conducted in Petri plates kept in the BOD incubator at $27 \pm 1{ }^{\circ} \mathrm{C}$ temperature, prior to the present investigation in which we considered only three of the higher doses with least inhibition/most germination. Seeds were treated with gamma rays $(100,200$ and $300 \mathrm{~Gy}), \mathrm{HZ}(0.1,0.2$ and $0.3 \%)$, SA $(0.01,0.02$ and $0.03 \%)$ and combination treatments of $\mathrm{HZ}$ and SA $(0.1 \% \mathrm{HZ}+.02 \% \mathrm{SA}, 0.2 \% \mathrm{HZ}+0.02 \% \mathrm{SA}$ and $0.3 \%$ $\mathrm{HZ}+.02 \% \mathrm{SA})$. For chemical mutagen treatments of both single and combination, the pre-soaked (9hrs) were subjected to $6 \mathrm{hrs}$ treatments of each doses of mutagen. Seeds were thoroughly washed in running tap water after that to remove any chemical residue attached. For physical treatment, dry seeds were directly irradiated with 100, 200 and 300 Gy of gamma rays with radioisotope 60Co, Cobalt- 60 , source chamber. The seeds were sown in 10 " $\times 15$ " pots to raise the $\mathrm{M}_{1}$ generation in the crop season 2014-2015. Seeds collected from $\mathrm{M}_{1}$ plants were sown in the next crop season (201516) to raise the $M_{2}$ generation. In $M_{1}$ generation, only the biological inhibition caused by the mutagen doses was calculated in rate of germination. While in $\mathrm{M}_{2}$ population, Descriptive data on quantitative traits were recorded and Duncan Multiple Range Test (DMRT) was applied using IBM SPSS 20.0 to determine the statistical significance of the variation created by different doses of mutagens. Morphological variations induced in the $\mathrm{M}_{2}$ population were recorded using descriptors for chickpea [IBPGR, ICRISAT and ICARDA, 1993], while also considering control population as standard. Phenotypic mutant frequency was calculated to determine the morphological response of the genotype used and the sensitivity of the different plant parts towards the doses. Pearson correlation matrix was also worked out to find the linear character associations between the different agronomic traits of interest.

\section{Results}

\subsection{Study in $M_{1}$ generation}

\subsubsection{Percentage germination and inhibition}

Percentage germination was recorded in both pots and petriplates in $\mathrm{M}_{1}$ generation. In both physical and chemical mutagen treated plants, the percentage seed germination declined with the increasing doses/concentrations. The maximum inhibition in germination was observed in combination treatment $0.3 \% \mathrm{HZ}+0.02 \% \mathrm{SA}(29.16 \%)$. The order of mutagens affecting the germination at higher doses/concentrations was found to be $\mathrm{HZ}+\mathrm{SA}>\mathrm{HZ}>$ gamma rays $>\mathrm{SA}$. In petriplates also, the maximum percentage inhibition was recorded in $0.3 \% \mathrm{HZ}+0.02 \% \mathrm{SA}$ $(22.22 \%)$. In petriplates, the order of mutagens affecting the germination at higher doses/concentrations was found to be $\mathrm{HZ}+\mathrm{SA}>\mathrm{HZ}>\mathrm{SA}>$ gamma rays (Table 1). 
Table 1. Effect of gamma rays, HZ, SA and combination treatments of $\mathrm{HZ}+\mathrm{SA}$ on percentage seed germination and inhibition of Cicer arietinum L. var. C-235.

\begin{tabular}{|c|c|c|c|c|}
\hline \multirow{2}{*}{ Treatments } & Germination \% & Inhibition \% & Germination \% & Inhibition \% \\
\hline & \multicolumn{2}{|c|}{ Pots } & \multicolumn{2}{|c|}{ Petriplates } \\
\hline Control & 95.83 & 4.16 & 100 & 0.00 \\
\hline $100 \mathrm{~Gy}$ & 95.83 & 4.16 & 100 & 0.00 \\
\hline $200 \mathrm{~Gy}$ & 87.5 & 12.5 & 94.44 & 5.55 \\
\hline $300 \mathrm{~Gy}$ & 83.33 & 16.66 & 94.44 & 5.55 \\
\hline $0.1 \% \mathrm{HZ}$ & 91.66 & 8.33 & 94.44 & 5.55 \\
\hline $0.2 \% \mathrm{HZ}$ & 83.33 & 16.66 & 88.88 & 11.11 \\
\hline $0.3 \% \mathrm{HZ}$ & 75.00 & 25.00 & 83.33 & 16.66 \\
\hline $0.01 \% \mathrm{SA}$ & 95.83 & 4.16 & 100.00 & 0.00 \\
\hline $0.02 \% \mathrm{SA}$ & 91.66 & 8.33 & 94.44 & 5.55 \\
\hline $0.03 \% \mathrm{SA}$ & 87.5 & 12.5 & 88.88 & 11.11 \\
\hline $0.1 \% H Z+0.02 \% \mathrm{SA}$ & 87.5 & 12.5 & 88.88 & 11.11 \\
\hline $0.2 \% \mathrm{HZ}+0.02 \% \mathrm{SA}$ & 79.16 & 20.83 & 83.33 & 16.66 \\
\hline $0.3 \% H Z+0.02 \% \mathrm{SA}$ & 70.83 & 29.16 & 77.77 & 22.22 \\
\hline
\end{tabular}

\subsection{Study in $M_{2}$ generation}

\subsubsection{Quantitative characters}

\section{A. Plant height}

In control plants, the mean height of plants was recorded as $50.06 \mathrm{cms}$ whereas, in treated plants the height ranged between $47.56-51.60 \mathrm{cms}$ (Table 2). The maximum height was observed in $100 \mathrm{~Gy}(51.60 \mathrm{cms})$ followed by $0.2 \% \mathrm{HZ}$ (51.36) whereas, the minimum height was observed in combination treatment of $0.3 \% \mathrm{HZ}+0.02 \% \mathrm{SA}(47.56 \mathrm{cms})$ followed by $0.3 \% \mathrm{HZ}(49.50 \mathrm{cms})$.

\section{B. Total number of branches per plant}

The mean number of branches per plant in control plants was observed as 13.53 while as in treated plants, it ranged between 7.96-10.46. The maximum number of total branches was observed in $0.2 \% \mathrm{HZ}$ (10.46) followed by $200 \mathrm{~Gy}(10.11)$.

\section{Fertile branches per plant}

The mean fertile branches per plant in control plants was observed as 9.33 whereas, in treated plants it ranged between 7.96-10.11. The highest number of fertile branches per plant was observed in $0.1 \% \mathrm{HZ}(10.46)$ whereas, the minimum number of branches was observed in $0.3 \% \mathrm{HZ}$ $+0.02 \%$ SA (7.96) (Table 2).

\section{Number of pods per plant}

The average number of pods per plant in control plant was observed as 30.26. Lower doses/concentrations increased the number of pods compared to control. The highest number of pods per plant was observed in $0.2 \% \mathrm{HZ}(33.36)$ followed by $0.2 \% \mathrm{HZ}+0.02 \% \mathrm{SA}(32.93)$ and $0.02 \%$ SA (32.80). 


\section{E. 100 seed weight $(\mathrm{g})$}

The yield of plants was calculated as the weight of 100 seeds in both untreated and treated plants. In control the average yield was observed as $22.26 \mathrm{~g}$ whereas, the lower doses/concentrations significantly increased the yield. The highest yield was observed in $0.2 \% \mathrm{HZ}$ $(24.06 \mathrm{~g})$ followed by $0.2 \% \mathrm{HZ}+0.02 \% \mathrm{SA}$ and $0.02 \% \mathrm{SA}(23.86 \mathrm{~g})$.

Table 2. Effect of gamma rays, HZ, SA and combination treatments of HZ+SA on quantitative characters of Cicer arietinum L. var. C-235.

\begin{tabular}{|c|c|c|c|c|c|}
\hline Treatments & $\begin{array}{c}\text { Plant height } \\
x \pm \text { S.E }\end{array}$ & $\begin{array}{c}\text { Number of } \\
\text { branches per } \\
\text { plant } \\
\mathbf{x} \pm \text { S.E }\end{array}$ & $\begin{array}{c}\text { Fertile } \\
\text { branches per } \\
\text { plant } \\
\mathbf{x} \pm \text { S.E }\end{array}$ & $\begin{array}{c}\text { Number of } \\
\text { pods per } \\
\text { plant } \\
\mathbf{x} \pm \text { S.E }\end{array}$ & $\begin{array}{c}100 \text { seed } \\
\text { weight } \\
x \pm \text { S.E }\end{array}$ \\
\hline Control & $50.06^{\mathrm{a}} \pm 0.78$ & $13.53^{\mathrm{ab}} \pm 0.63$ & $9.33^{\mathrm{abc}} \pm 0.32$ & $30.26^{\text {bcde }} \pm 1.32$ & $22.66^{\mathrm{abc}} \pm 0.66$ \\
\hline $100 \mathrm{~Gy}$ & $51.60^{\mathrm{a}} \pm 0.11$ & $13.66^{\mathrm{a}} \pm 0.33$ & $9.66^{\mathrm{abc}} \pm 0.03$ & $31.50^{\mathrm{abcd}_{ \pm 0}} \pm .17$ & $23.20^{\mathrm{abc}} \pm 0.05$ \\
\hline $200 \mathrm{~Gy}$ & $51.21^{\mathrm{a}} \pm 0.01$ & $14.47^{\mathrm{a}} \pm 0.03$ & $10.11^{\mathrm{ab}} \pm 0.008$ & $33^{\mathrm{ab}} \pm 0.05$ & $23.90^{\mathrm{a}} \pm 0.01$ \\
\hline $300 \mathrm{~Gy}$ & $49.68^{\mathrm{a}} \pm 0.04$ & $13.15^{\mathrm{ab}} \pm 0.02$ & $8.95 b^{c d} \pm 0.02$ & $29.60^{\mathrm{de}} \pm 0.05$ & $22.14^{\mathrm{c}} \pm 0.02$ \\
\hline $0.1 \% \mathrm{HZ}$ & $50.73^{\mathrm{a}} \pm 0.82$ & $14.13^{\mathrm{a}} \pm 0.65$ & $9.73^{\mathrm{abc}} \pm 0.26$ & $32.46^{\mathrm{abc}} \pm 0.66$ & $23.60^{\mathrm{ab}} \pm 0.58$ \\
\hline $0.2 \% \mathrm{HZ}$ & $51.36^{\mathrm{a}} \pm 0.84$ & $14.70^{\mathrm{a}} \pm 0.60$ & $10.46^{\mathrm{a}} \pm 0.50$ & $33.36^{\mathrm{a}} \pm 0.56$ & $24.06^{\mathrm{a}} \pm 0.31$ \\
\hline $0.3 \% \mathrm{HZ}$ & $49.50^{\mathrm{ab}} \pm 0.79$ & $13.03^{\mathrm{ab}} \pm 0.61$ & $8.73^{\mathrm{cd}} \pm 0.41$ & $29.53^{\mathrm{de}} \pm 1.32$ & $21.90^{\mathrm{c}} \pm 0.37$ \\
\hline $0.01 \% \mathrm{SA}$ & $50.30^{\mathrm{a}} \pm 0.79$ & $13.83^{\mathrm{a}} \pm 0.61$ & $9.56^{\mathrm{abc}} \pm 0.26$ & $30.83^{\mathrm{abcde}^{\mathrm{b}}} \pm 1.30$ & $23^{\mathrm{abc}} \pm 0.63$ \\
\hline $0.02 \% \mathrm{SA}$ & $51.06^{\mathrm{a}} \pm 0.82$ & $14.36^{\mathrm{a}} \pm 0.63$ & $10.06^{\mathrm{ab}} \pm 0.37$ & $32.80^{\mathrm{ab}} \pm 0.63$ & $23.86^{\mathrm{a}} \pm 0.44$ \\
\hline $0.03 \% \mathrm{SA}$ & $49.80^{\mathrm{a}} \pm 0.78$ & $13.26^{\mathrm{ab}} \pm 0.64$ & $9^{\mathrm{bcd}} \pm 0.40$ & $29.76^{\mathrm{cde}_{ \pm}} \pm 1.22$ & $22.26^{\mathrm{bc}} \pm 0.44$ \\
\hline $\begin{array}{c}0.1 \% \mathrm{HZ} \\
+0.02 \% \mathrm{SA}\end{array}$ & $50.93^{\mathrm{a}} \pm 0.84$ & $14.30^{\mathrm{a}} \pm 0.72$ & $10^{\mathrm{ab}} \pm 0.28$ & $32.63^{\mathrm{ab}} \pm 0.66$ & $23.86^{\mathrm{a}} \pm 0.60$ \\
\hline $\begin{array}{c}0.2 \% \mathrm{HZ} \\
+0.02 \% \mathrm{SA} \\
\end{array}$ & $50.80^{\mathrm{a}} \pm 0.65$ & $14.20^{\mathrm{a}} \pm 0.51$ & $10.03^{\mathrm{ab}} \pm 0.49$ & $32.93^{\mathrm{ab}} \pm 0.66$ & $23.23^{\mathrm{abc}} \pm 0.21$ \\
\hline $\begin{array}{c}0.3 \% H Z \\
+0.02 \% \mathrm{SA} \\
\end{array}$ & $47.56^{\mathrm{a}} \pm 0.21$ & $11.76^{\mathrm{b}} \pm 0.51$ & $7.96^{\mathrm{d}} \pm 0.55$ & $28.26^{\mathrm{de}} \pm 1.01$ & $19.96^{\mathrm{d}} \pm 0.08$ \\
\hline
\end{tabular}

\#Means within columns followed by the same letter is not different at the 5\% level of significance, based on the Duncan Multiple range test.

\subsubsection{Morphological mutations}

Different morphological mutants like tall, dwarf, bushy, one sided branches, broad and narrow leaf, broad pod and small pod were observed from $\mathrm{M}_{2}$ population (Table 3). Mutants like bushy, broad leaf and broad pod were observed in lower doses/concentrations of gamma rays, HZ, $\mathrm{SA}$ and lower combination treatment of $\mathrm{HZ}+\mathrm{SA}$ whereas, the higher doses/concentrations of gamma rays, HZ, SA and higher combination treatments of $\mathrm{HZ}+\mathrm{SA}$ produce the mutants like one sided branches, narrow leaf and narrow pod. 


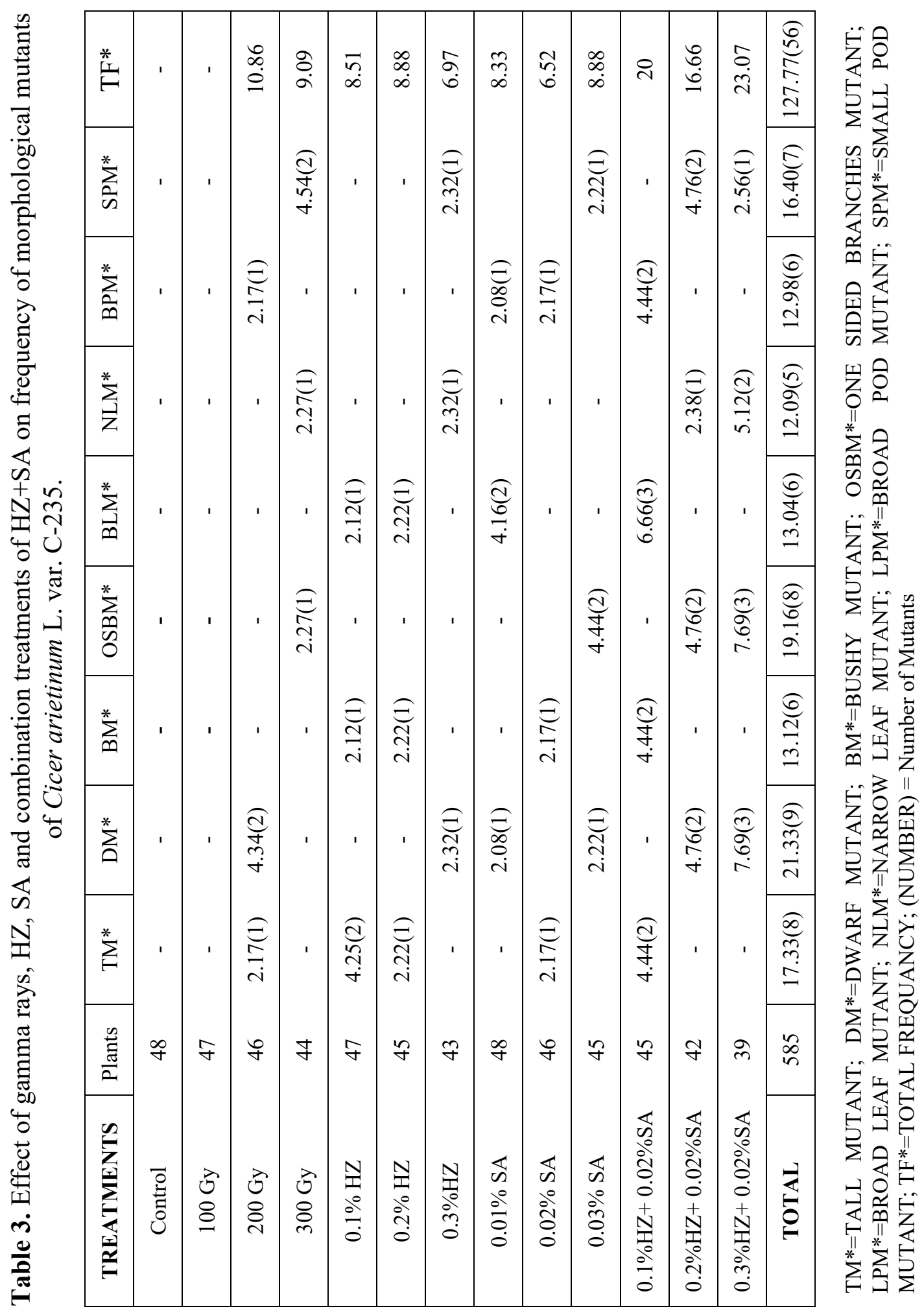




\subsubsection{Correlation studies of yield and its component traits}

Correlation data for different component traits are presented in Table 4. Correlation studies were observed for yield and its component traits in $\mathrm{M}_{2}$ population. Significant correlation was observed among all quantitative traits in $\mathrm{M}_{2}$ population. Yield showed significant and positive correlation with other components like pods, fertile branches at 0.01 significance level.

Table 4. Correlation coefficient matrix for yield and its component traits in $\mathrm{M}_{2}$ generation of Cicer arietinum L. var. C-235.

\begin{tabular}{|c|c|c|c|c|}
\hline CHARECTERS & Total branches & Fertile branches & Pods & Yield \\
\hline Plant height & $.923^{* *}$ & $.934^{* *}$ & $.881^{* *}$ & $.956^{* *}$ \\
\hline Total branches & - & $.986^{* *}$ & $.956^{* *}$ & $.987^{* *}$ \\
\hline Fertile branches & - & - & $.974^{* *}$ & $.972^{* *}$ \\
\hline Pods & - & - & - & $.935^{* *}$ \\
\hline
\end{tabular}

** $1 \%$ level of significance.

\section{Discussion}

The present experiment was conducted to assess the effect of both physical and chemical mutagenesis in Cicer arietinum L. var. C-235. The current experiment on different parameters revealed that the genotype is more sensitive to $\mathrm{HZ}$ and combination treatments than gamma rays and SA.

Percentage seed germination was observed to be decreased with increasing doses/concentrations of both physical and chemical mutagens. However, the effect was more pronounced in HZ than others, thus showing the more sensitivity of the genotype towards HZ. Reduction in seed germination may be due to the disturbed base pair relationship caused due to the effect of mutagens [1]. The available literature on germination inhibition due to mutagen doses suggested the inhibition of auxin synthesis, decline of assimilation mechanism and disturbance in enzyme formation may be the possible factors responsible [1].

Induced morphological mutations affecting key plant attributes generally regarded as promising from mutation breeder's point of view. In any mutation breeding programme, isolation and characterization of the morphological mutants in $\mathrm{M}_{2}$ progenies facilitate an important role in determining the genotypic sensitivity and mutagenic mutability. This assessment also assists to understand the mean deviation induced in the agronomic traits. In chickpea, several morphological mutants based on growth habit, size, leaf, flower and seeds were reported [4, 9, 14-17] with the application of single and combination treatments of physical and chemical mutagens. Since, every individual gene responsible for trait of agronomic interest can mutate, therefore, a wide spectrum of viable morphological mutants can be expected in mutation experiments [18]. Konzak [19] stated that the truly heritable morphological mutants like tall, dwarf, semidwarf, bushy, prostate and bold seeded mutant types were found to be controlled by polygenes whereas Reddy and Gupta [20] viewed that most of the true breeding mutants were governed by single recessive genes. Different morphological mutants like tall, dwarf, bushy, one sided branches, broad leaf and broad pod appeared in the $\mathrm{M}_{2}$ population with increasing frequency relative to the increasing doses. Enhancement of both frequency and spectrum of induce morphological mutations towards desired plant characteristics in a sustainable manner is key in mutation breeding experiment for crop improvement. Although identified morphological mutants cannot always be a predicted one and may contain undesirable attributes due to random mutational process, therefore, some mutants, nevertheless, could be used as a source of valuable genes in cross breeding programmes for quantitative traits improvement [16], may be constructive in mapping studies [21] and in evolutionary studies on the crops [15]. The pleiotropic effects of mutated genes or chromosomal aberrations or gene mutations might be responsible for such mutants [22]. 
The quantitative genetics theory concluded that the polygenic traits are governed by an array of genes with small but collective (additive) effect which can mutate in both directions with equal probability. Micro-mutations in genes controlling quantitative characters are important for crop improvement systems. In the present experiment, the mean deviation created in yield attributing traits due to the mutagenic treatments were found to be significant and also verifies the that low strength doses were more effective in increasing the mean values. Amin et al., [23] stated that it is imperative to know the interrelationships between agronomical polygenic traits for developing effective selection criteria for the desired trait without compromising other equally essential characters in lentil mutation breeding. Significant correlation was found among different quantitative traits, thus signifying the effectiveness of mutagens on the variety. It has also been reported that the mutagenesis can weaken or strengthen the association between different agronomic traits $[10,13]$. The increase in phenotypic and genotypic diversity in current crop using mutations can provide additional genetic markers for genetic enhancement and linkage studies. Correlation studies have become an important and useful tool in breeding to determine the selection criteria. Correlations studies in mutation breeding have already been reported by many workers $[9,10]$.

\section{Conclusions}

The present experiment was conducted to induce genetic variability in Cicer arietinum L. var. C-235 for improvement of agronomic traits. A linear dependence of observed traits on mutagenic doses was seen with each mutagen; however, combination treatments comparatively induced an enhanced effect on studied quantitative chickpea traits. Further, this can be arranged in the order $\mathrm{HZ}+\mathrm{SA}>\mathrm{HZ}>$ gamma rays $>\mathrm{SA}$ based on the efficacy. The treatment $0.3 \% \mathrm{HZ}+0.02 \% \mathrm{SA}$ produces highest frequency of morphological mutants followed by $0.2 \% \mathrm{HZ}+0.02 \% \mathrm{SA}$ and $200 \mathrm{~Gy}$ gamma rays treatments. Of all the mutant types, growth habit and leaf morphology were the most mutated characters in the var. C- 235 studied. The treatment $0.2 \% \mathrm{HZ}$ was found to be most effective in significantly producing highest positive deviation in all yield attributing traits studied. Correlation study supports the view that the mutagenic treatments could alter the mode of association between traits, apart from generating variability. Thus, the successful establishment of mutant population with wide genetic variability attained in the present work would be useful in the improvement of chickpea in a very sustainable manner.

\section{Conflict of Interest}

"There is no conflict of interest".

\section{Acknowledgements}

The authors are thankful to the Chairman, Department of Botany, A.M.U., Aligarh, for providing necessary facilities for carrying out this experiment and U.G.C., Govt. of India for financial assistance. 


\section{References}

[1] R. Roychowdhury, J. Tah, Assessment of chemical mutagenic effects in mutation breeding programme for $\mathrm{M}_{1}$ generation of Carnation (Dianthus caryophyllus), Research in Plant Biology. 1(4) (2011).

[2] A.K. Adamu, H. Aliyu, Morphogical effects of sodium azide on tomato (Lycopersicon esculentum Mill), Science World Journal. 2(4) (2007).

[3] M.C. Kharkwal, Q.Y. Shu, The role of induced mutations in world food security, Induced plant mutations in the genomics era. Food and Agriculture Organization of the United Nations, Rome. (2009) 33-38.

[4] R.A. Laskar et al., Quantitative analysis of induced phenotypic diversity in chickpea using physical and chemical mutagenesis, Journal of Agronomy. 14(3) (2015) 102.

[5] S. Khursheed et al., Comparative analysis of cytological abnormalities induced in Vicia faba L. genotypes using physical and chemical mutagenesis, Chromosome Science. 18 (2015).

[6] J.G. Manjaya, R.S. Nandanwar, Genetic improvement of soybean variety JS 80-21 through induced mutations, Plant Mutation Report (IAEA). 1(3) (2007) 36-41

[7] S. Khursheed, S. Khan, Genetic improvement of two cultivars of Vicia faba L. using gamma irradiation and ethyl methanesulphonate mutagenesis, Legume Research-An International Journal, (OF). (2016). DOI: 10.18805/lr.v0iOF.9614.

[8] S. Khursheed, S. Khan, Improvement of Yield and Mineral Content in Two Cultivars of Vicia faba L. Through Physical and Chemical Mutagenesis and their Character Association Analysis, Archives of Current Research International. 4(1) (2016).

[9] C. Toker, M.I. Cagirgan, Spectrum and frequency of induced mutations in chickpea, International Chickpea and Pigeonpea Newsletter. 11 (2004) 8-10.

[10] S. Khan, M.R. Wani, Genetic variability and correlations studies in chickpea mutants, J. Cytol. Genet. 6 (2005) 155-160.

[11] H. Ibrikci, S.J. Knewtson, M.A. Grusak, Chickpea leaves as a vegetable green for humans: evaluation of mineral composition, Journal of the Science of Food and Agriculture. 83 (2003) 945-950.

[12] S. Ramanujam, Chickpea: Cicer arietinum (Leguminosae-Papilionatae), Evolution of Crop Plants, NW Simmonds, 1976.

[13] J.M. Shin et al., Mutation breeding of sweet potato by gamma-ray radiation, African Journal of Agricultural Research. 6 (2011) 1447-1454.

[14] P.M. Gaur, V.K. Gour, A gene inhibiting flower colour in chickpea (Cicer arietinum L.), Indian J. Genet. 61(1) (2001) 41-44.

[15] C. Toker, A note on the evolution of kabuli chickpeas as shown by induced mutations in Cicer reticulatum Ladizinsky, Genet. Resour. Crop Evol. 56 (2009) 7-12.

[16] S. Khan, K. Parveen, S. Goyal, Induced mutations in chickpea-morphological mutants, Front. Agric. China.5(1) (2011) 35-39.

[17] S. Khan et al., Induction of morphological mutants in chickpea, International Chickpea and Pigeonpea Newsletter. 11 (2004) 6-7.

[18] B.S. Tyagi, P.K. Gupta, Induced macromutations in lentil, LENS Newsletter.18(1) (1991) 3-7.

[19] C.F. Konzak, S.C. Woo, J. Dickey, An induced semidwarf plant height mutation in spring wheat, Wheat Inf. Serv.28 (1969) 10-12. 
[20] V.R.K. Reddy, P.K. Gupta, Induced mutations in hexaploid triticale. Frequency and spectrum of morphological mutations, Genet. Agr. 42 (1988) 241- 254.

[21] P.M. Gaur, V.K. Gour, Broad-few-leaflets and outwardly curved wings: two new mutants of chickpea, Plant Breed.122 (2003) 192-194.

[22] M.R. Wani et al., Induction of morphological mutants in mugbean (Vigna radiata (L.) Wilczek) through chemical mutagens, The Nucleus. 48(3) (2011) 243-247.

[23] R. Amin, R.A. Laskar, S. Khan, Assessment of genetic response and character association for yield and yield components inLentil (Lens culinaris L.) population developedthrough chemical mutagenesis, Cogent Food and Agriculture. 1 (2015) 1000715.

[24] M.P. Kulthe, V.S. Kothekar, Effects of sodium azide on yield parameters of chickpea (Cicer arietinum L.), Journal of Phytology. 3(1) (2011) 39-42.

[25] DES. Agriculture Statistics at a Glance. Directorate of Economics and Statistics, Department of Agriculture and Economics, Ministry of Agriculture, Government of India, 2010. 